\title{
IDENTIFIKASI HAMBATAN PENGUKUHAN KAWASAN HUTAN DI PROVINSI RIAU
}

\section{(Identification of the Obstacles of Forest Area Designation in Riau Province)}

\author{
Eno Suwarno ${ }^{1}$ dan Abdul Wahib Situmorang ${ }^{2}$ \\ ${ }^{1}$ Fakultas Kehutanan Universitas Lancang Kuning, Jl. Yos Sudarso Km 8, Rumbai, Pekanbaru 28265, Indonesia, \\ E-mail: enosuwarno@unilak.ac.id; enosuwarno2009@gmail.com \\ ${ }^{2}$ United Nation Development Program (UNDP) Indonesia, Jl. MH. Thamrin Kav. 3 Menara Thamrin Building \\ 8th $-9^{\text {th }}$ floor Jakarta Pusat 10250 Indonesia, \\ E-mail: abdul.situmorang@undp.org
}

Diterima 27 Juli 2016, direvisi 9 Februari 2017, disetujui 3 Maret 2017

\begin{abstract}
The certainty of the status of forest area is an important prerequisite for the realization of good forest governance. However due to the error procedure in determining forest area in the past, which until now has not been improved, becoming one of the major obstacles to realizing that prerequisite. The study aim to identify the main obstacles of designation of forest areas in Riau Province, by using explanative research format and historical approach, while secondary data were collected from various sources. The time range study started in 1967 until 2015. The study found that the main obstacle was due to latent conflict on forest tenure between central government and other parties that have not been resolved. Conflict was begun with the issuance of Ministerial Decree number 173/ Kpts-II/1986 on Consensus-based Forest Land Use Planning that sets throughout the Riau province into forest areas.Besides, the regulatory regime on the affirmation of the existing forest area currently tend to be used as an instrument of affirmation of the right on the land rather than to set-up functions of forests. This point of view impact to the difficulty of completing the boundary demarcation task and establishment of forest area in the field.
\end{abstract}

Keyword: Designation of forest areas; latent conflict; Consensus-based Forest Land Use Planning

\begin{abstract}
ABSTRAK
Adanya kepastian status kawasan hutan menjadi prasyarat penting bagi terwujudnya tata kelola hutan yang baik. Namun dengan adanya kesalahan prosedur penetapan kawasan hutan di masa lalu yang hingga saat ini belum diperbaiki, menjadi salah satu kendala besar untuk mewujudkan kepastian kawasan hutan tersebut. Penelitian ini bertujuan untuk mengidentifikasi hambatan-hambatan utama pengukuhan kawasan hutan di Provinsi Riau dengan menggunakan format eksplanatif dan pendekatan sejarah, selain itu data sekunder dikumpulkan dari berbagai sumber. Rentang waktu kajian dimulai sejak tahun 1967 sampai dengan tahun 2015. Penelitian ini menemukan bahwa hambatan utama pengukuhan kawasanhutan adalah adanya konflik laten penguasaan lahan antara pemerintah dan pihak-pihak lainnya yang belum diselesaikan. Konflik berawal dari diterbitkannya Surat Keputusan Menteri Kehutanan Nomor 173/Kpts-II/1986 tentang Tata Guna Hutan Kesepakatan yang menetapkan seluruh wilayah Provinsi Riau menjadi kawasan hutan. Selain itu rezim peraturan pengukuhan kawasan hutan yang ada saat ini cenderung digunakan sebagai instrumen pengukuhan hak atas lahan daripada instrumen penataan fungsi hutan.Cara pandang ini berdampak kepada sulitnya menyelesaikan tugas tata batas dan penetapan kawasan hutan di lapangan.
\end{abstract}

Kata kunci: Pengukuhan kawasan hutan; konflik laten; Tata Guna Hutan Kesepakatan 


\section{PENDAHULUAN}

Berdasarkan Surat Keputusan (SK) Menteri Kehutanan Nomor SK.878/MenhutII/2014 Tentang Kawasan Hutan Provinsi Riau, saat ini Provinsi Riau memiliki kawasan hutan seluas 5,5 juta hektar. Kawasan hutan yang luas itu sebagiannya dalam kondisi open access dan menjadi arena kompetisi berbagai kepentingan pembangunan sektoral maupun masyarakat, baik legal maupun ilegal (Riausatu.com, 2016; WWFIndonesia, 2013). Maka adanya kepastian status kawasan hutan untuk mencegah kondisi open acces menjadi prasyarat penting bagi terwujudnya tata kelola hutan yang baik (Kartodihardjo, Nugroho, \& Putro, 2011; Suwarno et al., 2014).

Namun demikian, jalan menuju kepada kepastian kawasan hutan masih menghadapi berbagai kendala berat. Sampai akhir tahun 2015 kawasan hutan yang telah ditata batas mencapai $85,37 \%$, namun yang telah ditetapkan baru 16,63\%. Hal ini terjadi, selain karena masalah teknis dan anggaran, juga terutama disebabkan masih adanya konflik laten yang belum diselesaikan. Konflik berawal dari keluarnya SK Menteri Kehutanan Nomor173/Kpts-II/1986 Tentang Penunjukan Areal Hutan di Wilayah Provinsi Dati I Riau sebagai Kawasan Hutan, yang menetapkan seluruh wilayah administratif Provinsi Riau menjadi kawasan hutan. Hingga tahun 2013 telah dilakukan pelepasan kawasan hutan menjadi non kehutanan seluas 1.784 .713 hektar dari luas total 9.036.835 hektar, namun tidak ada satupun pelepasan untuk areal perkantoran pemerintah, infrastruktur, pusat kota dan desa, pemukiman dan lahan budidaya masyarakat. Semuanya hanya untuk lahan perkebunan besar dan lahan trasmigrasi (Tim Penelitian Terpadu, 2013).

Beberapa penelitian terdahulu terkait konflik kawasan hutan, antara lain Galudra \& Sirait (2009) menelusuri konflik lahan di Lampung melalui pendekatan sejarah hukum dan diskursus. Pemerintah kolonial Belanda menguasai lahan-lahan masyarakat melalui kebijakan sertifikasi. Lahan yang tidak bersertifikat secara otomatis menjadi lahan negara. Hal ini didasarkan pada asumsi bahwa negara memiliki kapasitas, legitimasi internal dan kemauan untuk mengelola semua sumber daya yang berada dalam seluruh wilayah negara. Setelah itu kemudian pemerintah kolonial Belanda melakukan deliniasi dan tata batas.

Verbist \& Pasya (2004) dan Abdul, Nurhaedah, \& Purwanti (2013) mengangkat konflik lahan antara masyarakat dan pemerintah di wilayah taman nasional. Masyarakat mendasarkan klaim lahan berpedoman kepada tata batas zaman kolonial Belanda, sementara pemerintah mengacu kepada Tata Guna Hutan Kesepakatan (TGHK) $)^{1}$ yang ditetapkan tahun 1980-an.

Bakker \& Moniaga (2010) mengkaji fenomena maraknya klaim masyarakat atas lahan hutan pasca reformasi. Beberapa sumber legitimasi yang digunakan antara lain: hak adat, sejarah penggunaan lahan, atau legalitas lahan yang resmi. Sinabutar, Nugroho, Kartodihardjo \& Darusman (2015) mengkaji aspek legitimasi hasil pengukuhan kawasan hutan di Provinsi Riau yang dilakukan pemerintah. Hasil kajiannya menemukan bahwa legitimasinya lemah dikarenakan tidak dilakukannya penyelesaian masalah klaim lahan dan dalam kegiatan tata batas proses partisipatifnya semu. Penelitian-penelitian terdahulu di atas belum ada yang mendalami bagaimana proses TGHK dilakukan serta menjelaskan situasi

1 TGHK singkatan dari Tata Guna Hutan Kesepakatan. TGHK adalah kesepakatan para pemangku kepentingan dari unsur pemerintah, untuk menentukan alokasi kawasan hutan di tingkat Provinsi berdasarkan fungsi pokoknya. Kesepakatan ini diprakarsai oleh Direktur Jenderal Kehutanan pada tahun 1981 yang melibatkan Departemen Agraria, Departemen Dalam Negeri dan Pemerintah Daerah. Hasil kesepakatan kemudian dituangkan di atas peta yang ditandatangani bersama. 
dan kondisi yang melatarbelakanginya. Demikian juga bagaimana perkembangan tahap berikutnya hingga sekarang tentang cara pemerintah bersikap setelah TGHK ditetapkan. Penelitian ini dimaksudkan untuk mengisi kekosongan tersebut sebagai upaya untuk menemukan masalah-masalah mendasar yang menghambat pengukuhan kawasan hutan di Provinsi Riau.

\section{METODE PENELITIAN}

Penelitian ini dilakukan untuk wilayah Provinsi Riau pada bulan Juni-Desember 2015. Data yang digunakan berupa data sekunder yang dikumpulkan dari berbagai sumber, yaitu dari buku, laporan penelitian, jurnal, website, dan lain-lain. Rentang waktu cakupan data secara historis dimulai sejak awal masa pemerintahan Orde Baru, 1967, sampai tahun 2015.

Penelitian ini menggunakan format eksplanatif, bertitik tolak dari pertanyaan dasar "mengapa" (Faisal, 2010) dengan pendekatan sejarah (historical approach). Pendekatan sejarah dimaksudkan untuk menceritakan sebuah cerita berdasarkan sumber-sumber yang kredibel berupa dokumen dan sumbersumber lain dalam konteks sejarah sehingga kita bisa lebih memahami maksud dari suatu kebijakan. Kebijakan pada dasarnya merupakan hasil dari suatu kebutuhan dan ketegangan yang terjadi di dalam masyarakat, yang dipicu oleh suatu kondisi dan peristiwa dan persepsi terkait dan reaksi terhadap kondisi-kondisi dan peristiwa tersebut. Dengan demikian unsur-unsur kontekstual adalah kunci dalam memahami bagaimana kebijakan muncul dan kemudian dibentuk (Hoefer, 2012).

Kerangka analisis menggunakan bagian dari Tools for Institutional, Political, and Social Analysis (TIPS) of Policy Reform yang dikembangkan (The World Bank, 2007). Pada level nasional, TIPS mengajukan analisis pada tiga aspek kontekstual, yaitu (1) analisis sosial, ekonomi, politik di tingkat nasional (country social analysis), (2) analisis kekuasaan (power analysis), dan (3) analisis pengendali perubahan (driver of cange).

\section{HASIL DAN PEMBAHASAN}

\section{A. Akar Masalah Pengukuhan Kawasan Hutan}

Pengukuhan kawasan hutan di Provinsi Riau tidak terlepas dari konteks sejarah dinamika sosial politik yang terjadi di tingkat nasional. Khususnya yang terjadi pada segmen fase peralihan kepemimpinan nasional dari Orde Lama kepada Orde Baru. Pada awal masa pemerintahannya, Orde Baru harus menghadapi krisis politik dan ekonomi yang parah. Kondisi tersebut ditandai dengan inflasi sangat tinggi dengan harga barang ratarata naik 500\%. Kurs pasar rupiah terhadap dolar Amerika jatuh dari Rp5.100 pada awal tahun 1965 menjadi Rp50.000 pada kuartal keempat (Ricklefs, 2005), laju petumbuhan negatif dan beban pembayaran hutang luar negeri yang berat (Robertson-snape, 1999), defisit anggaran pemerintah mencapai 175\% pada tahun 1965 (Mas'oed, 1989).

Untuk mengatasi keadaan tersebut pemerintah Orde Baru mengambil langkahlangkah revolusioner guna menciptakan stabilitas politik, keamanan dan ekonomi. Di bidang ekonomi ditempuh dengan kebijakan mempercepat pertumbuhan ekonomi. Kebijakan ini mau tidak mau membuat Indonesia harus "berorientasi ke luar" (Hidayat, 2008; Mas'oed, 1989).

Maka dimulailah era inventarisasi sumber-sumber daya alam yang bisa segera dieksploitasi. Salah satunya hutan, terutama hutan alam yang terdapat di luar Pulau Jawa. Bersamaan dengan itu pemerintah menyiapkan Undang-Undang dan peraturan turunannya sebagai landasan hukum bagi masuknya investasi. Maka secara berturutturut terbitlah Undang-Undang (UU) Nomor 1 Tahun 1967 Tentang Penanaman Modal Asing (PMA), UU Nomor 5 Tahun 1967 Tentang Pokok-Pokok Kehutanan (UUPK), dan UU 
Nomor 6 Tahun 1968 Tentang Penanaman Modal Dalam Negeri (PMDN), kemudian Peraturan Pemerintah (PP) Nomor 21 Tahun 1970 Tentang Hak Pengusaan Hutan (HPH) dan Hak Pemungutan Hasil Hutan (HPHH).

Pada tahun 1967 Presiden Soeharto menugaskan Direktur Jenderal Kehutanan dan timnya untuk melakukan kunjungan promosi ke berbagai negara. Di sisi lain, bagian perencanaan hutan menyiapkan kawasankawasan hutan yang akan dibebani ijin $\mathrm{HPH}$ (Djajapertjunda, 2013).

Hasilnya pada tahun tahun 1970-an sektor kehutanan menyumbangkan devisa kedua terbesar setelah minyak bumi. Konsesi HPH yang diberikan tanpa prosedur lelang antara tahun 1967-1980 diberikan kepada 519 HPH dengan luas wilayah 53 juta ha (Kartodihardjo \& Jhamtami, 2006). Pada tahun 1989 tercatat 572 unit ijin HPH yang menguasai 64 juta hektar hutan produksi Indonesia (Awang, 2006). Di Provinsi Riau sendiri pada tahun 1975 tercatat jumlah HPH 27 unit dengan luas konsesi 2,65 juta hektar. Pada tahun 1977 meningkat menjadi 42 unit dengan luas areal 4,21 juta hektar. Kemudian pada tahun 1979 meningkat lagi menjadi 59 unit dengan luas konsesi mencapai 5,12 juta hektar (Dinas Kehutanan Provinsi Riau, 2007).

Dengan latar belakang situasi seperti itulah proses-proses awal pengukuhan kawasan hutan di Indonesia dilakukan. Dalam keadaan serba kekurangan dana, sumber daya manusia dan teknologi, pemerintah melakukan pengukuhan kawasan hutan secara makro di atas peta, tanpa melalui proses inventarisasi dan tata batas di lapangan. Proses ini antara lain dapat diketahui dari pernyataan Djajapertjunda \& Djamhuri (2013) yang menyatakan "..... melalui Surat Keputusan Menteri Pertanian Nomor 291/Kpts/Um/1970 Tentang Penetapan Areal Kerja Pengusahaan Hutan sebagai Hutan Produksi, kemudian secara otomatis ditetapkan menjadi Kawasan Hutan Produksi dalam Lingkungan Kawasan Hutan Negara".
Adapun gambaran yang lebih rinci tentang situasi diterbitkannya UUPK Nomor 5 Tahun 1967 serta mekanisme pengukuhan kawasan hutan pada saat itu dapat diikuti dari paparan salah seorang pelaku sejarah, Sadikin Djajapertjunda, pada Kotak 1 dan Kotak 2 di bawah ini.

Berdasarkan penuturan Sadikin Djajapertjunda di atas, dapat ditangkap suasana yang tengah dihadapi Bangsa Indonesia pada saat itu. Negara, selain sedang mengalami krisis politik, juga sedang menghadapi krisis ekonomi yang sangat parah, sehingga membutuhkan langkah-langkah tanggap darurat untuk menanggulanginya. Oleh karena itu sumber-sumber daya yang ada harus segera bisa dimanfaatkan, salah satunya sumber daya hutan. Kepentingan "harus segera menghadirkan investasi swasta" seolah menjadi pembenaran bagi diberlakukannya prosedur "jalan pintas". Antara lain dalam mekanisme pengukuhan kawasan hutan. Keberadaan pemukiman dan kepentingan masyarakat lokal yang sudah berada turun-temurun di dalam kawasan hutan, bahkan keberadaan kantor pemerintah pun dikesampingkan saat itu. Hal ini dibuktikan dengan dikeluarkannya SK Menteri Kehutanan Nomor 173/Kpts-II/1986 Tentang Penunjukan Areal Hutan di Wilayah Provinsi Dati I Riau sebagai Kawasan Hutan yang menetapkan seluruh (atau 100\%) wilayah Provinsi Riau sebagai kawasan hutan.

Situasi demikian antara lain diungkap Wrangham (2003), yang menyatakan bahwa secara bersama-sama UUPK dan sejumlah PP telah menciptakan kerangka bagi eksploitasi ekonomi sumber daya alam Indonesia secara sistematik oleh perusahaan-perusahaan besar melalui proses klasifikasi dan demarkasi areal hutan dan kemudian melarang akses atau pemanfaatan sumber daya tersebut oleh masyarakat lokal. Adanya dominasi pemegang konsesi hutan, menunjukan gagasan kuat akan pengusahaan hutan daripada pengelolaan hutan dan adanya ketidakpercayaan terhadap masyarakat. 


\section{Kotak 1. Sejarah lahirnya Undang-Undang Pokok Kehutanan (UUPK) Nomor 5 Tahun 1967 untuk mendukung investasi sektor kehutanan}

\section{(Box 1. The history of Forestry Law (UUPK) No. 5 of 1967 to support the forestry sector investment)}

Pada pertengahan tahun 1964, penulis sebagai Pembantu Dekan II Fakultas Kehutanan Institut Pertanian Bogor telah mendengar berita bahwa Presiden Soekarno telah membentuk Departemen Kehutanan dalam Kabinet Dwikora. Selain itu Bapak Soedjarwo Kepala Dinas Kehutanan D.I. Yogyakarta telah diangkat sebagai Menteri Kehutanan. Salah satu program pemerintah waktu itu adalah meningkatkan produksi barang yang dapat diekspor dan salah satu andalannya adalah dari sektor kehutanan. Program tersebut dilakukan untuk meningkatkan pendapatan devisa. Para pejabat di Departemen Kehutanan yakin bahwa bila dana investasi disediakan cukup memadai, nilai ekspor hasil hutan dari sektor kehutanan akan dapat ditingkatkan. Investasi yang cukup besar akan sulit diperoleh dari pemerintah, sehingga partisipasi swasta sangat diperlukan (Djajapertjunda, 2013:1).

Jajaran pejabat di Departemen Kehutanan telah sepakat bahwa rencana peningkatan produksi dan ekspor akan membutuhkan dana investasi yang cukup besar, sehingga perlu diatur dengan peraturan yang lebih memadai. Sehubungan dengan itu menteri kehutanan menginstruksikan kepada para pembantunya untuk segera menyelesaikan konsep Undang-Undang Kehutanan yang baru. Konsep tersebut kelak akan digunakan sebagai induk bagi peraturan-peraturan pemerintah dan peraturan lain yang diperlukan (Djajapertjunda, 2013:2). Menteri kehutanan menegaskan bahwa Undang-Undang Pokok Kehutanan (UUPK) sudah sangat diperlukan dan diminta agar konsep yang sudah disempurnakan dapat segera diajukan kepada DPRGR. Isi substansi rancangan UUPK yang diusulkan tersebut sebenarnya merupakan "reinkarnasi" dari Bosreglement Tahun 1927 dengan berbagai penyempurnaan yang diperlukan (Djajapertjunda, 2013:4).

Ketika konsep tersebut diajukan dalam rapat Departemen Kehutanan, Menteri Kehutanan menerima pandangan-pandangan cukup menarik yang disampaikan oleh LSM. Rapat tersebut dihadiri oleh berbagai pemangku kepentingan. Pandangan menarik antara lain dari Sarbuksi yang meminta agar Panitia PKUUPK dapat berdialog langsung dengan pengurus Sarbuksi untuk menyampaikan pandangan-pandangannya. Masukan lainnya yang sangat penting dari LSM Sarbuksi adalah sebagai berikut:

1. Jalan pikiran Panitia PKUUPK dipengaruhi oleh kepentingan kolonialisme yang mendahulukan swasta untuk melaksanakan pengusahaan hutan dan tidak menghargai kepentingan rakyat.

2. Panitia PKUUPK tidak memperhatikan kepentingan demokrasi karena masyarakat di daerah tidak diberi kesempatan turut mengelola hutan. Demokrasi yang diusulkannya agar di daerah dibentuk Dewan Pembina Kehutanan yang anggota-anggotanya terdiri atas para pemangku kepentingan.

Para pejabat yang menghadiri rapat tersebut tidak banyak yang menyanggah, tetapi mengusulkan perbaikanperbaikan beberapa pasal dan redaksi agar lebih sempurna. Beberapa masalah yang hangat dibicarakan pada rapat-rapat bulan Juni 1965 adalah mengenai hal-hal sebagai berikut (salah satunya, pen):

Masalah pengukuhan hutan yang dijelaskan oleh Bapak Hasan Basyaruddin Nasution bahwa pengukuhan hutan harus segera dilaksanakan karena hutan yang dikukuhkan baru mencapai 14 juta hektar. Oleh karena itu, masalah pengukuhan hutan harus dicantumkan sebagai salah satu pasal dalam konsep UUPK. Penulis mengajukan usul, apakah tidak sebaiknya bahwa SK pengukuhan hutan dibuat dengan SK Presiden. Usul penulis tidak disetujui karena cara itu akan memakan waktu, SK Presiden harus melalui proses yang panjang (Djajapertjunda, 2013:5-6).

Sumber: Catatan Seorang Rimbawan: Mendongkrak Investasi HPH dan Promosi Ekspor Kayu Indonesia (Djajapertjunda, 2013) 
Kotak 2. Sejarah pengukuhan kawasan hutan dalam bingkai Undang-Undang Pokok Agraria Nomor 5 Tahun 1960

(Box 2. The history of forest areas designation in the Agrarian Law No. 5 of 1960 Frame)

Setelah melalui perdebatan yang panjang antara departemen-departemen yang terkait, pada tahun 1960 Undang-Undang Pokok Agraria (UUPA) diterbitkan. Makna undang-undang ini sangat penting, terutama menyangkut pemanfaatan hutan cadangan yang sebagian besar belum dikuasai. Dengan keluarnya undang-undang tersebut, hutan cadangan dapat dimanfaatkan untuk kepentingan umum dan pembangunan. Sesuai dengan kebijakan pemerintah, rencana pemanfaatan hutan untuk diusahakan dengan cara lebih teratur mulai disiapkan. Pada waktu itu, masalah-masalah agraria diurus oleh suatu badan yang bernaung di bawah Departemen Pertanian. Undang-Undang Agraria yang diundangkan sebenarnya mengandung banyak ketetapan yang digunakan dalam Agrarische Wet 1870 di zaman Belanda sebagai ketetapan-ketetapan yang berdasarkan Hukum Barat, di antaranya menyatakan bahwa tanah-tanah yang tidak dapat dibuktikan kepemilikannya adalah tanah negara (pernyataan domein) (Djajapertjunda \& Djamhuri, 2013: 196).

Rencana penggunaan lahan pada umumnya ditetapkan dalam rapat-rapat antar-instansi di bawah pimpinan Pemerintah Daerah bersama dengan Kepala Urusan Agraria yang bersangkutan, karena rencana tata ruang pada waktu itu belum ada. Hutan yang ada dikategorikan sebagai hutan negara bebas yang belum dijadikan kawasan hutan karena sebagian hutan di luar Jawa belum dikukuhkan. Selain itu proses pengukuhan hutan yang telah diatur oleh peraturan-peraturan yang berlaku tidak dapat dilaksanakan dengan cepat karena harus melalui berbagai prosedur. Luas kawasan hutan tetap yang sudah dikukuhkan di seluruh Indonesia yang tercatat pada tahun 1950 adalah 16,8 juta hektar, termasuk hutan negara di Pulau Jawa. Salah satu hal yang penting dalam undang-undang tersebut adalah pengakuan terhadap berlakunya hukum adat terhadap tanah-tanah yang disebutkan bahwa sepanjang masih ada dan berlaku dengan kewajiban agar melepaskan haknya apabila tanah tersebut diperlukan untuk kepentingan umum, kepentingan pemerintah atau untuk kepentingan pembangunan (Djajapertjunda \& Djamhuri, 2013: 197).

Untuk dapat melaksanakan semua program yang telah dituangkan dalam peraturan-peraturan tersebut, diperlukan adanya Perencanaan Kehutanan yaitu kegiatan menyusun rencana kegiatan dalam memanfaatkan hutan. Pelaksana di bidang perencanaan adalah Direktorat Inventarisasi dan Perencanaan Kehutanan (DITINPEK). Tugas yang dibebankan kepada DITINPEK dan Direktorat Pembinaan Hutan, di antaranya mempelajari kawasan- kawasan yang memiliki kemungkinan untuk diusahakan. Sekalipun hutan-hutan yang berpotensi untuk diusahakan belum dikukuhkan seluruhnya, tetapi sepanjang didapatkan kawasan-kawasan hutan yang diperkirakan secara ekonomis dapat diusahakan dan disetujui oleh Pemerintah.

Sumber: Sumber: Hutan dan Kehutanan Indonesia dari Masa Ke Masa (Djajapertjunda \& Djamhuri, 2013)

\section{B. Berlanjut Terus: Belum Ada Upaya Penyelesaian yang Sungguh-Sungguh}

Belakangan, cara penguasaan lahan seperti itu mendapat kritik tajam dari berbagai kalangan. Antara lain Peluso (2006) di dalam bukunya yang berjudul "Hutan Kaya, Rakyat Miskin: Penguasaan Sumber Daya dan Perlawanan di Jawa" mengatakan "Negara kolonial dan negara masa kini sering mengambil alih kawasan yang luas sebagai hutan, untuk perkebunan, atau untuk proyek pembangunan yang besar, merampas dan mencampakkan sistem hak-hak kepemilikan tanah yang sudah lebih dulu ada dan menetapkan aturan hukum yang baru untuk tata guna tanah dan sumber daya. Seringkali pengambilalihan ini diberi alasan pembenar dalam klaim bahwa perubahan itu demi "kepentingan bersama" bagi "kemaslahatan 
sebesar-besarnya" (Peluso, 2006). Dalam banyak kasus, negara begitu saja mengingkari legitimasi sistem hak kepemilikan yang ada sebelumnya atas lahan dan sumber daya alam lain berbasis tanah, sehingga negara menetapkan hubungan-hubungan baru dengan sarana-sarana produksi tersebut. Penduduk yang bermukim di hutan atau petani yang bergantung pada hutan lebih dirugikan ketimbang diuntungkan oleh penguasaan sentralistis negara atas hutan cadangan atau perkebunan hutan (Blaikie, 1985 dalam Peluso, 2006). "Hilangnya otonomi relatif dan akses mereka pada hutan menjadi sangat parah manakala negara menggunakan penguasaannya untuk memonopoli eksploitasi sumber daya" (Peluso, 2006).

Prosedur pengukuhan kawasan hutan "jalan pintas", dengan menapikkan fakta keberadaan masyarakat yang sudah ada secara turun-temurun dan memiliki ketergantungan hidup yang tinggi terhadap hutan, jelas sangat berpotensi memendam konflik laten dan massif. Hasil identifikasi desa di dalam dan sekitar hutan tahun 2009 oleh Departemen Kehutanan dan Badan Pusat Statistik diperoleh data desa hutan berjumlah 70.429 buah di seluruh wilayah Indonesia, sementara di Provinsi Riau terdapat 1.480 buah desa (Dephut \& BPS, 2009).

Oleh karena itu seyogianya prosedur seperti itu harus dipandang sebagai cara sementara dalam situasi darurat. Namun sayangnya setelah situasinya berubah pemerintah belum pernah melakukan perubahan kebijakan yang mendasar terkait penetapan kawasan hutan.

Di Provinsi Riau, fakta ini dapat dilihat dari kebijakan alokasi pelepasan kawasan hutan oleh Departemen/ Kementerian Kehutanan. Berdasarkan Surat Keputusan Menteri Kehutanan Nomor 173/Kpts-II/1986, kawasan hutan di Provinsi Riau seluas 8.598.757,00 ha, namun setelah diperbaharui pada tahun 2012 menjadi $9.036 .835,00$ ha seperti pada Tabel 1 .

Dari HPK seluas 1.769.966,27 ha, selama kurun waktu 37 tahun (1986-2013) telah dikonversi menjadi kawasan penggunaan lain seluas 1.714.431,73 ha, seperti pada Tabel 2.

Fakta di lapangan, pemukiman masyarakat di dalam kawasan hutan tersebar di seluruh fungsi kawasan hutan, baik di hutan lindung, kawasan konservasi, hutan produksi, maupun di hutan produksi yang dapat dikonversi.

Tabel 1. Luas Kawasan Hutan Provinsi Riau Berdasarkan TGHK

(Table 1. The Riau Forest Areas Distribution base on TGHK)

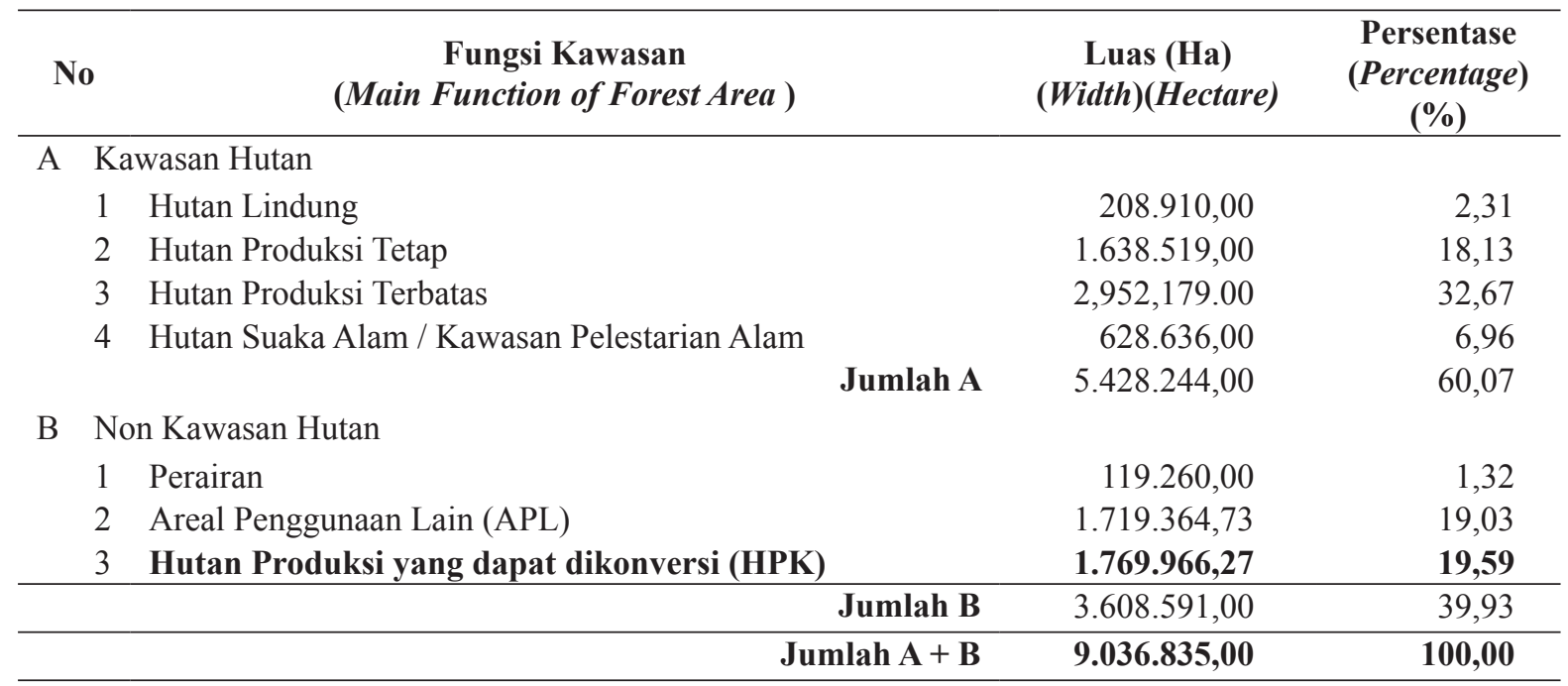

Sumber (Source): Website Dinas Kehutanan Provinsi Riau, 2013. 
Namun berdasarkan data pada Tabel 2, terlihat bahwa pelepasan kawasan hutan hanya dilakukan untuk izin perkebunan (Hak Guna Usaha/HGU) dan lahan transmigrasi. Sama sekali tidak ada pelepasan untuk pemukiman tua, pengembangan desa, atau bahkan perkantoran pemerintah.

Hasil analisis Tim Terpadu (Timdu) Dalam Rangka Penelitian Perubahan Peruntukan dan Fungsi Kawasan Hutan juga menyatakan hal yang sama, bahwa semua kawasan hutan yang dilepaskan selama periode 1986-2013 adalah untuk perkebunan besar; tidak ada untuk pembangunan infrastruktur seperti jalan, pusat pemerintahan, dan perkotaan; juga tidak ada untuk pemukiman dan lahan garapan masyarakat. Di sisi lain, jumlah penduduk terus meningkat, pusat-pusat pemerintahan dan perkotaan terus berkembang (Tim Penelitian Terpadu, 2013).

Berdasarkan PP Nomor 10 Tahun 2010 jo. PP Nomor 60 Tahun 2012 Tentang Tata Cara Perubahan Peruntukan dan Fungsi Kawasan Hutan, memang pelepasan kawasan hutan baru akan diproses apabila ada pihak yang mengusulkan. Usulan bisa berasal dari menteri atau pejabat setingkat menteri, gubernur atau bupati/walikota, pimpinan badan usaha, atau ketua yayasan. Namun secara faktual, belum pernah ada inisiatif dari Kementerian Kehutanan usulan untuk melepaskan pemukiman-pemukiman tua atau perkantoran pemerintah yang ada di dalam kawasan hutan. Data tersebut mengindikasikan bahwa sejak tahun 1967 hingga sekarang pemerintah tidak pernah secara sungguh-sungguh menyelesaikan masalah kepastian hukum secara adil bagi masyarakat desa hutan yang sudah bermukim sejak sebelum dikeluarkannya UU Agraria Tahun 1960.

Kebijakan pelepasan kawasan hutan yang berlaku pada periode tahun 1986-2013 dapat ditelusuri dari sejumlah peraturan yang diterbitkan oleh pemerintah. Pada UU Nomor 5 Tahun 1967 Tentang Pokok-Pokok Kehutanan belum secara eksplisit mengatur tentang pelepasan kawasan hutan. Demikian juga dengan peraturan turunannya yaitu PP Nomor 33 Tahun 1970 Tentang Perencanaan Hutan. Pelepasan kawasan hutan secara eksplisit baru diatur pada Keputusan Menteri Kehutanan (Kepmenhut) Nomor 145/ Kpts-II/1986 Tentang Ketentuan Pelepasan Kawasan Hutan untuk Pengembangan Usaha Budidaya Pertanian. Kepmenhut ini kemudian diganti oleh Surat Keputusan Bersama (SKB) Menteri Kehutanan, Menteri Pertanian dan Kepala Badan Pertanahan Nasional Nomor 364/Kpts-II/90, Nomor 519/Kpts/HK.050/90: 23-VIII-1990 Tentang Ketentuan Pelepasan Kawasan Hutan dan Pemberian Hak Guna Usaha untuk Pengembangan Usaha Pertanian. SKB ini hanya mengatur pelepasan kawasan hutan untuk menjadi lahan usaha pertanian yang langsung dikuasai oleh negara (Badan Usaha Milik Negara), tidak untuk keperluan lainnya.

Pasca reformasi terbit UU Nomor 41 Tahun 1999 Tentang Kehutanan sebagai pengganti UU Nomor 5 Tahun 1967. Berdasarkan UU ini perubahan peruntukan dan fungsi kawasan hutan ditetapkan oleh Pemerintah dan diatur melalui Peraturan Pemerintah (Pasal 19). Maka lahirlah PP Nomor 10 Tahun 2010 jo. PP Nomor 60 Tahun 2012 Tentang Tata Cara Perubahan Peruntukan dan Fungsi Kawasan Hutan. Berdasarkan PP ini bentuk pelepasan kawasan hutan ada dua, yaitu pelepasan kawasan hutan secara parsial (PKHP) dan pelepasan kawasan hutan wilayah provinsi (PKHWP). PKHP berdasarkan usulan dari menteri atau pejabat setingkat menteri, gubernur atau bupati/walikota, pimpinan badan usaha, atau ketua yayasan (Pasal 8) dan hanya dapat dilakukan pada hutan produksi yang dapat dikonversi (Pasal 19). Sedangkan PKHWP dapat dilakukan pada hutan konservasi, hutan lindung, dan hutan produksi (Pasal 29) berdasarkan usulan dari gubernur kepada Menteri yang diintegrasikan dalam revisi rencana tata ruang wilayah provinsi (Pasal 30). Bila dicermati dengan menggunakan konsep rules-in-use Ostrom 
(Kalaba, 2016; Suwarno et al., 2015), semua peraturan tersebut tidak ada satu pun yang memberi posisi (position rules) kepada masyarakat desa hutan untuk terlibat dalam mekanisme pelepasan kawasan hutan.

Terkait fenomena ini, (Ritchie, 2014) menyebutnya sebagai gejala inersia pemerintah. Inersia pemerintah -dalam arti menghindari pembuatan keputusan untuk menghasilkan hasil yang lebih efisien secara sosial- adalah sebagai dampak dari kombinasi formalisasi birokrasi, penghindaran terhadap risiko dari para pegawai pemerintah, dan adanya struktur insentif yang saat ini dinikmati para pihak sehingga mendorong kepada penolakan keputusan untuk berubah. Terjadinya inersia pemerintah, menurut Nordberg (2007) juga disebabkan oleh karena adanya kepentingan politik jangka pendek dan kepentingan ekonomi, sehingga proses reformasi yang membutuhkan waktu relatif lama dan alokasi sumber daya yang besar menjadi cenderung diabaikan. Padahal, menurut Reich (1995), reformasi yang luas hanya mungkin terjadi bila ada kemauan politik yang cukup dan ketika perubahanperubahan dirancang dan dilaksanakan oleh para perencana dan pelaksana yang handal. Politik akan memengaruhi asal, perumusan dan pelaksanaan kebijakan publik terutama ketika perubahan yang signifikan diperlukan. Contohnya seperti keberhasilan program rehabilitasi hutan di Vietnam, dimana pemerintahnya telah menetapkan rehabilitasi hutan sebagai program prioritas sejak pertengahan 1950-an dan ditingkatkan sejak awal 1990-an. Proyek-proyek ini dilakukan pada skala nasional dengan dukungan dana yang sangat besar baik dari dalam maupun luar negeri (Jong, Arts, \& Krott, 2012).

Apa yang diuraikan di atas dimaksudkan untuk memberikan gambaran keterkaitan antara masalah pengukuhan kawasan hutan yang dihadapi saat ini dengan salah satu akar masalah yang pernah dilakukan pemerintah di masa lalu.

\section{Ada Salah Kaprah dalam Memaknai Pengukuhan Kawasan Hutan}

Pengukuhan kawasan hutan saat ini diatur dalam Undang-Undang (UU) Nomor 41 Tahun 1999 Tentang Kehutanan (Pasal 12), kemudian Peraturan Pemerintah (PP) Nomor 44 Tahun 2004 Tentang Perencanaan Hutan (Pasal 15). Pada tingkat operasionalnya diatur dalam Permenhut Nomor P.44/MenhutII/2012 jo. P.62/Menhut II/2013 Tentang Pengukuhan Kawasan Hutan. Berdasarkan Permenhut tersebut pengukuhan kawasan hutan terdiri dari tiga rangkaian kegiatan, yaitu: penunjukan, penataan batas, dan penetapan kawasan hutan. Kawasan hutan sendiri didefinisikan sebagai wilayah tertentu yang ditetapkan oleh Pemerintah untuk dipertahankan keberadaannya sebagai "hutan tetap".

Dalam prakteknya pengukuhan kawasan hutan di Indonesia seringkali ditujukan untuk menetapkan hak negara atas kawasan hutan tertentu yang memisahkannya dengan lahan milik masyarakat. Dengan kata lain, mekanisme pengukuhan kawasan hutan telah dipandang dan digunakan sebagai instrumen untuk menetapkan hak kepemilikan (property right) kawasan hutan daripada sebagai instrumen untuk penataan fungsi kawasan hutan.

Cara pandang ini antara lain dapat diidentifikasi dari definisi "tata batas kawasan hutan". Penataan batas kawasan hutan adalah kegiatan yang meliputi pembuatan peta trayek batas, pemancangan batas sementara, pengumuman hasil pemancangan batas sementara, inventarisasi, identifikasi dan penyelesaian hak-hak pihak ketiga, pembuatan dan penandatanganan berita acara tata batas sementara dan peta lampiran tata batas, pemasangan tanda batas dan pengukuran batas, pemetaan hasil penataan batas, pembuatan dan penandatanganan berita acara tata batas dan peta tata batas.

Adanya frase "invetarisasi, identifikasi dan penyelesaian hak-hak pihak ketiga" 
mengindikasikan adanya pembatasan bahwa letak kawasan hutan (sebagai hutan tetap) harus selalu berada di hutan negara, tidak pada lahan milik masyarakat. Padahal bila pendekatannya fungsi hutan, maka keberadaan atau lokasi hutan tetap bisa saja berada pada lahan milik masyarakat.

Terjadinya "kekasaran prosedur" pengukuhan kawasan hutan di masa lalu, dan penyalahartian makna tata batas saat ini berimplikasi kepada beratnya tugas (bahkan gagalnya) menyelesaikan proses-proses pengukuhan kawasan hutan di lapangan. Terutama pada tahap penataan batas kawasan hutan. Pelaksanaan penataan batas kawasan hutan di Indonesia pada umumnya akan berhadapan dengan klaim-klaim penggunaan lain dan kepemilikan (property right) masyarakat, baik yang sudah turun-temurun berada di dalam kawasan hutan maupun yang masih baru.

Di Provinsi Riau bahkan proses pengukuhan kawasan hutan berjalan stagnan. Sampai tahun 2013 dari luas kawasan hutan 4.288.957,82 ha $(11.126,35 \mathrm{~km})$, baru dilakukan penetapan seluas $\pm 1.850,67$ ha atau sepanjang $\pm 561.428,74 \mathrm{~km}(16,63 \%)$, padahal telah ditata batas sepanjang 9.499,02 km $(85,37 \%)$ (Sinabutar, Nugroho, Kartodihardjo, \& Darusman, 2015).

Selain permasalahan mendasar yang telah diungkapkan di atas, hasil penelitian Sinabutar et al., (2015) mengungkapkan sejumlah masalah operasional proses pengukuhan kawasan hutan di Provinsi Riau. Tiga masalah penting di bawah ini menggambarkan dampak lebih lanjut dari adanya permasalahan laten yang sudah ada sebelumnya:

a. Dalam penunjukan kawasan hutan, peta yang digunakan sebagai dasar untuk membuat trayek batas berbeda antara Kementerian Kehutanan (diwakili Balai Pemantapan Kawasan Hutan atau BPKH) dengan Pemerintah Provinsi Riau dan Pemerintah Kabupaten /Kota di Provinsi Riau.BPKHmengacukepadapetalampiran SK Menteri Kehutanan Nomor173/Kpts-
II/1986 tentang Penunjukan Areal Hutan di Wilayah Provinsi Dati I Riau sebagai Kawasan Hutan (PKH Riau), sementara Pemerintah Daerah (termasuk Badan Pertanahan Nasional, Badan Perencanaan Pembangunan Daerah, dan lain-lain) mengacu kepada peta lampiran Peraturan Daerah (Perda) Nomor 10 Tahun 1994 Tentang Rencana Tata Ruang Wilayah Provinsi Riau. Peta trayek batas tetap dibuat berdasarkan peta PKH Riau, namun dalam pelaksanaan pemancangan batas sementara disesuaikan dengan usulan tim tata ruang dengan menggunakan instrumen "in" dan "out". Penataan batas tetap dilakukan, namun hasilnya tidak memiliki legalitas dan legitimasi karena hanya dihasilkan sepihak oleh BPKH.

b. Panitia tata batas cenderung menghindari konflik untuk menghindari kegagalan tata batas. Penyelesaian klaim belum sepenuhnya dilakukan, padahal Peraturan Menteri Kehutanan Nomor P.44/MenhutII/2012 jo. P.62/Menhut-II/ 2013 Tentang Pengukuhan Kawasan Hutan sudah membuka ruang penyelesaian dengan melengkapi bukti hak secara tertulis maupun tidak tertulis. Petugas lebih fokus menyesuaikan titik koordinat dilapangan dengan peta trayek batas dibanding mengungkap bukti klaim.

c. Indikator kinerja tata batas bukan pada legitimasi namun pada panjang batas definitif. Hal itu dipertegas lagi dalam Permenhut Nomor P.37/MenhutII/2013 Tentang Pedoman Pemantauan dan Pengukuran Kinerja Kementerian Kehutanan tahun 2013 yang menjelaskan bahwa indikator kinerja tata batas adalah panjang batas definitif berdasarkan laporan tata batas yang memuat Berita Acara Tata Batas (BATB) dan notulen rapat. Hal itu bermakna bahwa kinerja tata batas tidak mencakup aspek legitimasi.

Klaim-klaim yang diajukan oleh masyarakat ataupun penggunaan kawasan hutan secara non prosedural oleh berbagai 
pihak, bisa saja bersifat lama atau baru. Bagi yang sudah berlangsung lama, hal ini mungkin bisa dimaklumi. Namun terhadap klaimklaim baru yang disertai dengan pembukaan dan pendudukan kawasan hutan, pelanggaran ini pun nyaris tidak bisa dimonitor dan dikendalikan oleh pemerintah. Demikian juga dengan terjadinya banyak tumpang tindih izin, menunjukan lemahnya monitoring dan pengendalian pengelolaan hutan oleh pemerintah di tingkat tapak. Hal ini terjadi karena pada sebagian kawasan hutan, terjadi kondisi open access akibat tidak adanya unit-unit instansi pemerintah yang secara khusus setiap hari bertugas untuk menjaga dan menguatkan intensitas pengelolaan hutan di tingkat tapak. Situasi ini semakin mempersulit pelaksanaan dan penyelesaian tugas pengukuhan kawasan hutan. Dengan demikian maka dari perspektif kelembagaan, keberadaan instansi pemerintah sebagai unit pengelola hutan di tingkat tapak menjadi sangat penting.

\section{KESIMPULAN DAN SARAN}

\section{A. Kesimpulan}

Berdasarkan uraian di atas dapat disimpulkan bahwa kekasaran prosedur pengukuhan kawasan hutan pada awal pemerintahan Orde Baru menyimpan bibit konflik laten dan massif antara pemerintah dan masyarakat, dan antara instansi pemerintah sendiri hingga sekarang. Pemerintah telah melakukan pengukuhan kawasan hutan secara makro di atas peta, tanpa melalui proses inventarisasi dan tata batas di lapangan.

Masalah fundamental ini sampai saat ini belum pernah dikoreksi dan diselesaikan oleh pemerintah, sehingga berdampak kepada sulitnya pelaksanaan tata batas dan penetapan kawasan hutan di lapangan. Penetapan kawasan hutan akan banyak berhadapan dengan masalah klaim dan berbagai keterlanjuran. Adanya desa di dalam dan sekitar hutan sebanyak 70.429 buah di seluruh wilayah Indonesia, dan 1.480 buah desa di Provinsi Riau sudah cukup untuk menggambarkan rumitnya masalah ini.

Terjadinya fenomena inersia pemerintah untuk menghasilkan kebijakan yang reformatif diduga sebagai dampak dari kombinasi formalisasi birokrasi, penghindaran terhadap risiko dan adanya struktur insentif yang saat ini dinikmati para pihak, sehingga mendorong kepada penolakan keputusan untuk berubah. Selain itu adanya kepentingan politik jangka pendek, kepentingan ekonomi, dan kurangnya koordinasi di antara lembaga-lembaga pemerintah, menyebabkan proses reformasi yang membutuhkan waktu relatif lama dan alokasi sumber daya yang besar menjadi cenderung diabaikan.

Rezim peraturan pengukuhan kawasan hutan yang ada saat ini cenderung dipandang dan digunakan sebagai instumen pengukuhan hak (property right) atas kawasan hutan daripada sebagai instrumen penataan fungsi hutan. Cara pandang seperti ini juga akan berdampak kepada sulitnya menyelesaikan tugas tata batas dan penetapan kawasan hutan oleh pelaksana di tingkat lapangan, karena akan berhadapan dengan konflik klaim lahan. Situasi ini memunculkan perilaku tim tata batas yang cenderung mengejar target fisik dan administratif dengan menghindari aspek legitimasi.

Ketiadaan instansi pemerintah yang secara khusus bertugas untuk mengelola hutan di tingkat tapak - khususnya untuk hutan lindung dan hutan produksi- yang sudah berlangsung sangat lama, seolah membuka pintu bagi maraknya klaim-klaim baru dan pemanfaatan kawasan hutan secara non prsedural. Situasi ini semakin mempersulit pelaksanaan dan penyelesaian tugas pengukuhahan kawasan hutan.

\section{B. Saran}

1. Perlu ada pengakuan yang tulus dari pemerintah bahwa cara penetapan kawasan hutan di masa lalu (contohnya melalui SK Menteri Pertanian Nomor 291/Kpts/Um/1970 Tentang Penetapan 
Areal Kerja Pengusahaan Hutan) masih mengandung banyak kelemahan dan kesalahan. Maka perlu ada proses koreksi total yang diselaraskan dengan paradigma pembangunan kehutanan yang berorientasi kepada keadilan sosial, pertumbuhan ekonomi dan kelestarian sumber daya alam sesuai dengan amanat UndangUndang Dasar (UUD) 1945.

2. Sebagai turunan dari paradigma baru, indikator utama kinerja tata batas bukan hanya bersifat fisik dan administratif, namun selesainya substansi masalah yaitu terpenuhinya aspek legalitas sekaligus adanya pengakuan sosial (legitimasi) terhadap property right kawasan hutan.

3. Selain itu, perlu ada koreksi terhadap cara pandang yang menganggap pengukuhan kawasan hutan sebagai mekanisme penetapan hak (property right) atas lahan atau kawasan hutan, yang memisahkan antara hutan negara dan lahan milik masyarakat. Pengukuhan kawasan hutan mestinya dipandang dan digunakan sebagai mekanisme menetapkan fungsifungsi hutan, baik pada hutan negara maupun pada lahan milik. Bila cara pandang yang pertama tetap dipegang, maka pemerintah akan selalu menghadapi kesulitan ketika melaksanakan seluruh tahapan pengukuhan kawasan hutan (penunjukan, tata batas, dan penetapan), dan berpeluang besar terjadinya kegagalan pada seluruh tahapanpengukuhan.

4. Guna meningkatkan intensitas monitoring, pengendalian, pelayanan dan merespon berbagai dinamika sehari-hari yang terjadi di tingkat tapak, pembangunan Kesatuan Pengelolaan Hutan (KPH) perlu diberi dukungan yang besar dan dipercepat.

\section{UCAPAN TERIMA KASIH (ACKNOWLEDGEMENT)}

Penulis mengucapkan terima kasih kepada Direktorat Penelitian dan Pengembangan Komisi Pemberantasan Korupsi (Litbang KPK) yang telah memberikan kepercayaan kepada penulis untuk melaksanakan penelitian ini. Ucapan terima kasih juga disampaikan kepada United Nation Development Program (UNDP) Indonesia, yang telah mendukung pendanaan untuk pelaksanaan penelitian ini.

\section{DAFTAR PUSTAKA}

Abdul K.W, Nurhaedah, M., \& Purwanti, R. (2013). Konflik pada kawasan Taman Nasional Bantimurung Bulusaraung Provinsi Sulawesi Selatan dan upaya penyelesaiannya. Jurnal Penelitian Sosial dan Ekonomi Kehutanan, 10(3), 186-198.

Awang, S.A. (2006). Sosiologi pengetahuan deforestasi: Konstruksi sosial dan perlawanan. Yogyakarta: Debut Press.

Bakker, L., \& Moniaga, S. (2010). The Space Between : Land claims and the law in Indonesia. Asian Journal of Social Science, 38, 187-203. doi:// doi.org/10.1163/156853110X490890

Dephut \& BPS. (2009). Identifikasi desa di dalam dan di sekitar hutan 2009. Jakarta: Departemen Kehutanan dan Badan Pusat Statistik.

Dinas Kehutanan Provinsi Riau. (2007). Sejarah kehutanan Riau. Pekanbaru: Dinas Kehutanan Provinsi Riau.

Djajapertjunda, S. (2013). Catatan seorang rimbawan: Mendongkrak investasi HPH dan promosi ekspor kayu Indonesia. Bogor: IPB Press.

Djajapertjunda, S., \& Djamhuri, E. (2013). Hutan dan kehutanan Indonesia dari masa ke masa. Bogor: IPB Press.

Faisal, S. (2010). Format-format penelitian sosial. Jakarta: PT Raja Grafindo Persada.

Galudra, G., \& Sirait, M. (2009). A Discourse on Dutch colonial forest policy and science in Indonesia at the beginning of the 20th century. International Forestry Review, 11(4), 524533.

Hidayat, H. (2008). Politik lingkungan: Pengelolaan hutan orde baru dan orde reformasi. Jakarta: Yayasan Obor Indonesia. 
Hoefer, R. (2012). Policy creation and evaluation: Undertanding welfare reform in the United States. Retrieved November 15, 2016, from www.oup.com

Jong, W. De, Arts, B., \& Krott, M. (2012). Forest policy and economics political theory in forest policy science. Forest Policy and Economics, 16, 1-6. doi://doi.org/10.1016/j. forpol.2011.07.001

Kalaba, F.K. (2016). Barriers to policy implementation and implications for Zambia's forest ecosystems. Forest Policy and Economics, 69, 40-44. doi:// doi.org/10.1016/j.forpol.2016.04.004

Kartodihardjo, H., \& Jhamtami, H. (2006). Politik lingkungan dan kekuasaan di Indonesia. Jakarta: Equinox Publishing.

Kartodihardjo, H., Nugroho, B., \& Putro, H.W. (2011). Pembangunan kesatuan pengelolaan hutan (KPH): Konsep, peraturan perundangan dan implementasi. (A. Djajono \& L. Siswanty, Eds.). Jakarta: Direktorat Wilayah Pengelolaan dan Penyiapan Areal Pemanfaatan Kawasan Hutan bekerja sama dengan Deutsche Gesellschaft fur Internationale Zusammenarbeit (GIZ) GmbH-FORCLIME Forest and Climate Change Programme.

Keputusan Menteri Kehutanan Nomor 145/KptsII/1986 Tentang Ketentuan Pelepasan Kawasan Hutan untuk Pengembangan Usaha Budidaya Pertanian.

Mas'oed, M. (1989). Ekonomi dan struktur politik: Orde baru 1966-1971. Jakarta: LP3ES.

Nordberg, M. (2007). Ukraine reforms in forestry 1990-2000. Forest Policy and Economics, 9, 713-729. doi:// doi.org/10.1016/j.forpol.2006.07.002

Peluso, N. (2006). Hutan kaya, rakyat miskin: Penguasaan sumber daya dan perlawanan di Jawa. Jakarta: Konphalindo.

Peraturan Menteri Kehutanan Nomor P. 37/MenhutII/2013 Tentang Pedoman Pemantauan dan Pengukuran Kinerja Kementerian Kehutanan tahun 2013

Peraturan Menteri Kehutanan Nomor P.44/MenhutII/2012 jo. P.62/Menhut-II/2013 Tentang Pengukuhan Kawasan Hutan.

Peraturan Pemerintah Nomor 21 Tahun 1970 Tentang Hak Pengusaan Hutan (HPH) dan Hak Pemungutan Hasil Hutan (HPHH).

Peraturan Pemerintah Nomor 33 Tahun 1970 Tentang Perencanaan Hutan.
Peraturan Pemerintah Nomor 44 Tahun 2004 Tentang Perencanaan Hutan.

Reich, M.R. (1995). The politics of health sector reforms in developing countries: Three cases of pharmaceutical policy. Health Policy, 32, 47-77.

Riausatu.com. (2016). Pansus lahan DPRD Riau laporkan 636.245,44 hektar lahan tanpa izin. Retrieved December 17, 2016, from http:// www.riausatu.com/read-11-11860-201601-30-pansus-lahan-dprd-riau-laporkan63624533-hektar-lahan-tanpa-izin.html

Ricklefs, M.C. (2005). Sejarah Indonesia modern 1200-2004 (3rd ed.). Jakarta: PT Serambi Ilmu Semesta.

Ritchie, F. (2014). Resistance to change in government : risk, inertia and incentives. Bristol: University of the West of England.

Robertson-snape, F. (1999). Corruption, collusion and nepotism in Indonesia. Third World Quarterly, 20(3), 589-602. doi://doi. org/10.1080/01436599913703

Sinabutar, P., Nugroho, B., Kartodihardjo, H., \& Darusman, D. (2015). Kepastian hukum dan pengakuan para pihak hasil pengukuhan kawasan hutan negara di Provinsi Riau. Jurnal Analisis Kebijakan Kehutanan, 12(1), 27-40.

Surat Keputusan Bersama Menteri Kehutanan, Menteri Pertanian dan Kepala Badan Pertanahan Nasional Nomor 364/Kpts-II/90, Nomor 519/Kpts/HK.050/90: 23-VIII-1990 Tentang Ketentuan Pelepasan Kawasan Hutan dan Pemberian Hak Guna Usaha untuk Pengembangan Usaha .

Surat Keputusan Menteri Kehutanan Nomor SK.878/ Menhut-II/2014 Tentang Kawasan Hutan Provinsi Riau.

Surat Keputusan Menteri Kehutanan Nomor173/KptsII/1986 Tentang Penunjukan Areal Hutan di Wilayah Provinsi Dati I Riau.

Surat Keputusan Menteri Pertanian Nomor 291/Kpts/ Um/1970 Tentang Penetapan Areal Kerja Pengusahaan Hutan sebagai Hutan Produksi.

Suwarno, E., Ichsan, A.C., Simanjuntak, L., Nababan, A.B., Lesmana, D., \& Nanggara, S.G. (2014). Panduan penilaian kinerja pembangunan dan pelaksanaan kesatuan pengelolaan hutan di wilayah KPH: Dengan menggunakan kriteria dan indikator FWI 1.0. Retrieved December 13, 2016, from fwi.or.id

Suwarno, E., Kartodihardjo, H., Kolopaking, L.M., \& Soedomo, S. (2015). Penggunaan konsep 
rules-in-uses ostrom dalam analisis peraturan pembentukan organisasi kesatuan pengelolaan hutan. Jurnal Analisis Kebijakan Kehutanan, 12(1), 13-26.

The World Bank. (2007). Tools for institutional, political, and social analysis of policy reform. Washington DC: The World Bank.

Tim Penelitian Terpadu. (2013). Laporan hasil penelitian terpadu usulan perubahan kawasan hutan dalam pemaduserasian TGHK dengan recana tata ruang wilayah Provinsi Riau. Jakarta: Kementerian Kehutanan RI.

Undang-Undang Nomor 1 Tahun 1967 Tentang Penanaman Modal Asing.

Undang-Undang Nomor 5 Tahun 1967 Tentang PokokPokok Kehutanan.

Undang-Undang Nomor 6 Tahun 1968 Tentang Penanaman Modal Dalam Negeri.
Undang-Undang Nomor 41 Tahun 1999 Tentang Kehutanan

Verbist, B., \& Pasya, G. (2004). Perspektif sejarah status kawasan hutan, konflik dan negoisasi di Sumberjaya, Lampung Barat - Provinsi Riau. AGRIVITA, 26(1), 20-28.

Wrangham, R. 2003. Diskursus kebijakan yang berubah dan masyarakat adat, 1960-1999. Dalam Resosudarmo, I.A.P, Colfer, C.J.P. (Eds.) Kemana harus melangkah? Masyarakat, hutan, dan perumusan kebijakan di Indonesia. Jakarta: Yayasan Obor Indonesia. hlm. 24-42.

WWF-Indonesia. (2013). Menelusuri TBS sawit ilegal dari kompleks hutan Tesso Nilo. Retrieved December 17, 2016, from http:// awsassets.wwf.or.id/downloads/wwf indonesia_2013_menelusuri_sawit_ illegal_di_riau_final.pdf 